удК 338:62

1. О. Маланчук,

к. i.н., дочент кафедри державного управління, документознавста та інформачійної

діяльності, Начіональний університет водного господарства та природокористування

ORCID ID: 0000-0002-6341-5639

C. C. Синютич,

магістрант, Начіональний університет водного господарства

та природокористування, м. Рівне

ORCID ID: 0000-0003-4743-9021

DOI: $10.32702 / 2306-6814.2021 .20 .121$

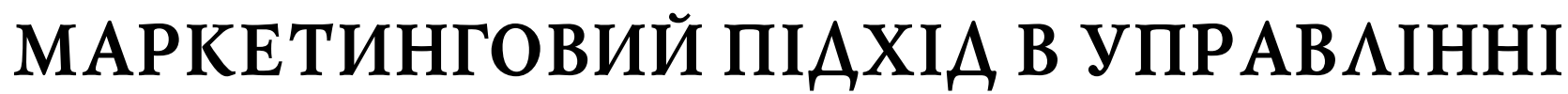 РОЗВИТКОМ ТЕРИТОРІї
}

\author{
L. Malanchuk, \\ $\mathrm{PhD}$ in Historical Sciences, Associate Professor of the Department of Public Administration, \\ Documentation and Information Activity, National University of Water Management and Nature Management \\ C. Sinyutych, \\ Master's student, National University of Water Management and Environmental Sciences, Rivne
}

\section{MARKETING APPROACH IN TERRITORIAL DEVELOPMENT MANAGEMENT}

Територіальний розвиток був і залишається одним з найактуальніших питань, які потребують вирішення з точки зору надання можливостей для розбудови потенціалусучасного суспільства.

В умовах ринкової економіки, зосередженої на інтенсифікації споживання та орієнтуванні продуктів та послуг, вироблених на цих територіях, на спочатку визначені внутрішні та зовнішні цільові аудиторії, філософія управління маркетингом, розкрита в рамках територіального маркетингу, здається, є затребуваною у плануванні та виконання планів територіального розвиткy.

Процеси глобалізації та інтеграції, виражені вільним переміщенням матеріальних і нематеріальних ресурсів з метою пошуку найбільш вигідних сфер їх застосування, отримали свій активний розвиток У другій половині XX ст., i сприяли розвитку положень теорії маркетингу територій.

Теорія маркетингу пройшла довгий еволюційний шлях від концепції вдосконалення виробництва до соціально-етичного маркетингу, ідея якого полягає в тому, що споживання товару має вести до зміцнення добробуту в довгостроковій перспективі не лише конкретного споживача, а й суспільства загалом. Терміни "маркетинг", "просування", "імідж", "залучення споживача" прийшли до нас з мікромаркетинга (маркетингу підприємства), однак концепція маркетингу в сучасних умовах цілком застосовна і для управління розвитком території. Розвиток ринкових сил і конкуренція змушують будь-яку місцевість вигідно подавати себе. Адже за інших рівних умов від того, як території країни себе позиціонують, залежить, чи отримають вони потрібні інвестиції, чи притягнуть вигідні проєкти, міжнародні ярмарки, конгреси, туристів. Суперництво змушує території піклуватися про свої образи, ламати невигідні для себе стереотипи і будувати сприятливі.

У статті розглянуто сутність маркетингу території за різними підходами, розкрито основні групи стратегії, які застосовуються в маркетингу територій. Визначено основні суб'єкти, які здійснюють маркетинг території та розглянуто цілі та завдання, які ставлять перед ними.

Зазначено, що маркетинг території націлений на отримання максимального соціального ефекту, просування території та забезпечення ії соціально-економічного розвитку. Результат важко кількісно виміряти, оперує якісними характеристиками. 
Territorial development has been and remains one of the most pressing issues that need to be addressed in terms of providing opportunities for building the potential of modern society.

In a market economy focused on the intensification of consumption and the targeting of products and services produced in the territories to initially determined internal and external target audiences, the marketing management philosophy disclosed in the framework of territorial marketing seems to be in demand in the planning and implementation of territorial development plans.

The processes of globalization and integration, expressed by the free movement of tangible and intangible resources in order to find the most profitable areas of their application, were actively developed in the second half of XX century, and contributed to the development of marketing theory.

Marketing theory has come a long way from the concept of improving production to socio-ethical marketing, the idea of which is that the consumption of goods should lead to a strengthening of welfare in the long run not only for a particular consumer but also for society as a whole. The terms "marketing", "promotion", "image", "consumer involvement" came to us from micromarketing (enterprise marketing), but the concept of marketing in modern conditions is quite applicable to manage the development of the territory. The development of market forces and competition force any area to present itself favorably. After all, other things being equal, it depends on how the country's territories position themselves, whether they will receive the necessary investments, whether they will attract profitable projects, international fairs, congresses, and tourists. Rivalry forces territories to take care of their images, break stereotypes that are unfavorable to them and build favorable ones.

The article considers the essence of territory marketing by different approaches, reveals the main groups of strategies used in the marketing of territories. The main subjects that market the territory are identified and the goals and objectives set for them are considered.

It is noted that the marketing of the territory is aimed at obtaining the maximum social effect, promoting the territory and ensuring its socio-economic development. The result is difficult to quantify, operates with qualitative characteristics.

Ключові слова: маркетинг територій, стратегія, суб'єкти територіального маркетингу, завдання територіального маркетингу.

Key words: marketing of territories, strategy, subjects of territorial marketing, tasks of territorial marketing.

\section{АНА $\Lambda$ I ОСТАHНIX АОС $\Lambda$ IАЖЕHЬ І ПУБАІКАЦІЙ}

Дослідження проблем територіального маркетингу, конкурентоспроможності та ринкового позиціонування територій займалися такі зарубіжні та вітчизняні вчені: К. Асплунд, В. Вакуленко, І. Дробязко, С. Єрємєєв, В. Кірдін, І. Князєва, Ф. Котлер, А. Крилов, А. Лавров та багато інших.

\section{ПОСТАНОВКА ПРОБАЕМИ}

Маркетинг як одна з концепцій управління вже тривалий час успішно застосовується за кордоном і в Україні на мікрорівні. Однак на рівні територій, маркетингові методи і інструменти використовуються на практиці не в повній мірі. У зв'язку з цим дотепер маркетинговий потенціал територій України залишається недостатньо реалізованим.

\section{META CTATTI}

Метою статті $€$ дослідження сутності та ролі маркетингу в управлінні розвитком території, а також виявити основні напрямки по фрормуванню маркетингового потенціалу території, що впливає на її ринкове позиціонування.

\section{ВИК ААА ОСНОВНОГО МАТЕРІААУ}

Соціально-економічний розвиток будь-якої території фрокусується сьогодні на підвищенні її конкурентоспроможності шляхом збереження і використання наявних, а також формування і реалізації нових конкурентних переваг, що визначають позиціонування території.

Науковий і практичний інтерес до дослідження сутності конкурентоспроможності території та ефрективного її позиціонування, викликав зростаючий інтерес тео- 
ретиків і практиків до інструментів виявлення і створення конкурентних переваг, які позначені досить ємним поняттям "маркетинг території".

Концептуальні підходи до дослідження категорії "маркетинг територій", що дозволяють виявити ключову характеристику представлені в таблиці 1.

Узагальнюючи думки вчених, можна зробити висновок, що основною метою маркетингу території $€$ її моделювання або планування для задоволення потреб споживачів її ресурсів. Якщо вони задоволені своїм місцем проживання і ведення господарської діяльності, а очікування приїжджих і інвесторів виправдалися, то соціально-економічні показники системи мають позитивну динаміку. Застосування інструментів маркетингу територій відбивається на економічних показниках регіональної системи.

Отже, маркетинг територій - це конвергенція управлінських і економічних видів діяльності суб'єктів територіальної системи управління за погодженням можливого виробництва і потреб споживачів ресурсів території, шляхом регулювання взаємозв' язків і співвідношень їх розвиткy.

Основними суб'єктами територіального маркетингу $є$ територіальні органи влади і управління, які залучають до участі, можливо, координують зусилля і інших потенційних суб'єктів, до яких відносять некомерційні організації (спортивні товариства та федерації, національні земляцтва і професійні спілки); комерційні організації (туристичні компанії, авіакомпанії, об'єкти гостинності та дозвілля, торговельні та промислові підприємства); приватні особи - жителі території і відомі особистості, які проживають на цій території (майстри народних промислів, носії самобутньої культури і мови); інші структури, локалізовані на території, які проявляють активність, діють в інтересах суспільства і основною метою своєї діяльності вважають успішний соціально-економічний розвиток території для комфортного проживання та безпечного ведення діяльності комерційного та некомерційного характеpy.

До основних завдань, що стоять перед суб'єктами територіального маркетингу, відносить ефективну політику по залученню зарубіжних і внутрішніх інвестицій;
. Теоретичні підходи до дослідження категорії "маркетинг територій"

\begin{tabular}{|l|l|l|}
\hline \multicolumn{1}{|c|}{ Підхід } & \multicolumn{1}{|c|}{ Автор } & \multicolumn{1}{|c|}{ Сутність категорії «маркетинг територій» } \\
\hline Ідеологічний & $\begin{array}{l}\text { І.В. Арженовський } \\
\text { та інші }\end{array}$ & $\begin{array}{l}\text { Ключове слово: передова ідея, філософія. } \\
\text { Характеристика: застосування маркетингових } \\
\text { інструментів }\end{array}$ \\
\hline Системний & $\begin{array}{l}\text { Г. Вуд, В.Б. Зотов, } \\
\text { А.М. Лавров та } \\
\text { iнші }\end{array}$ & $\begin{array}{l}\text { Ключове слово: система управління, елемент } \\
\text { системи ринкових відносин. } \\
\text { Характеристика: мета системи - аналіз і облік } \\
\text { потреб цільових споживачів; діагностика стану і } \\
\text { динаміки кон'юнктури ринку; мега- і мезорівні } \\
\text { для забезпечення якості життя населення }\end{array}$ \\
\hline Ресурсний & $\begin{array}{l}\text { С. Ворд, } \\
\text { А.Л. Гапоненко, } \\
\text { Дж. Голд та інші }\end{array}$ & $\begin{array}{l}\text { Ключове слово: інструмент використання і (або) } \\
\text { створення конкурентних переваг. } \\
\text { Характеристика: основна мета підвищення } \\
\text { конкурентоспроможності та іміджу території }\end{array}$ \\
\hline Поведінковий & $\begin{array}{l}\text { Г. Даффі, } \\
\text { В.Г. Старовойтов } \\
\text { та інші }\end{array}$ & $\begin{array}{l}\text { Ключове слово: діяльність по зміні поведінки } \\
\text { зовнішніх суб'єктів по відношенню до конкретної } \\
\text { території. } \\
\text { Характеристика: розмежування зовнішніх і } \\
\text { внутрішніх об'єктів впливу }\end{array}$ \\
\hline Сервісний & $\begin{array}{l}\text { Л. Ван ден Берг, } \\
\text { Я. Мир, У. Функе } \\
\text { та інші }\end{array}$ & $\begin{array}{l}\text { Ключове слово: діяльність по оптимізації послуг } \\
\text { території і попиту на них населення, підприємств, } \\
\text { туристів та ін. } \\
\text { Характеристики: пошук оптимуму економічного } \\
\text { розвитку }\end{array}$ \\
\hline Процесний & $\begin{array}{l}\text { Ю.Н. Старцев } \\
\text { та інші }\end{array}$ & $\begin{array}{l}\text { Ключове слово: задоволення потреб території } \\
\text { шляхом внутрішнього і зовнішнього обміну }\end{array}$ \\
\hline Са інші & $\begin{array}{l}\text { Ключове слово: політика державних органів влади. } \\
\text { Характеристика: створення сприятливих умов для } \\
\text { життя населення, що забезпечує } \\
\text { конкурентоспроможність території }\end{array}$ \\
\hline
\end{tabular}

фрормування і поліпшення іміджу території, її престижу, ділової та соціальної конкурентоспроможності; збереження і нарощування інтелектуального потенціалу за рахунок розвитку науки і освіти; створення сприятливих умов для розвитку малого і середнього підприємництва; розвиток фрінансових інститутів; розширення інститутів соціального захисту населення.

На рисунку 1 представлено основні групи стратегій, які застосовуються в маркетингу територій.

Маркетинг іміджу. Мета: створення, розвиток і поширення позитивного образу території.

Маркетинг привабливості. заходи, спрямовані на підвищення привабливості даної території для людини.

Маркетинг інфраструктури. На території повинно бути зручно жити, працювати і розвиватися, а для цього потрібно насамперед розвивати інфрраструктуру житлових районів, промислових зон, ринкову інфрраструктуру.

Маркетинг населення, персоналу. Території, що характеризуються різним станом справ, проблемами і потребами в сорері зайнятості, вибирають різні стратегії. Так, території з низьким рівнем зайнятості і дешевою

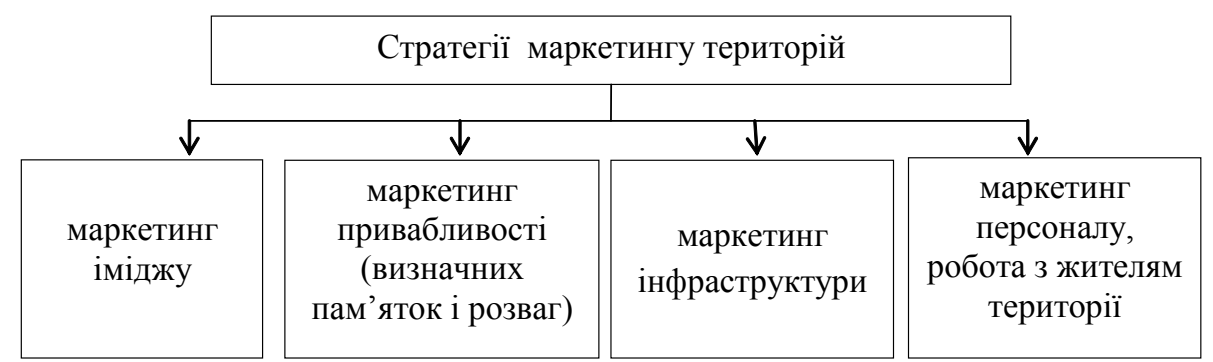

Рис. 1. Стратегїі маркетингу території

Джерело: [4, с. 76]. 
робочою силою можуть висувати це як аргумент для залучення промисловців, підприємців сфери послуг та інше з метою створення нових робочих місць [3].

Регіональний просторовий розвиток багато в чому реалізується в рамках напрямку, обгрунтованого в теоретичних положеннях центрально-периферійної моделі. Маркетингове забезпечення розвитку територій, поєднане передусім із залученням інвестицій, також здійснюється в рамках цієї парадигми. Основні іміджеві стратегії регіонів націлені на пошук варіантів співпраці з успішними інноваційними, промисловими та іншими центрами, пошук ділових партнерів та внутрішніх і зовнішніх інвесторів. Пріоритетними представляються рішення, націлені на залучення інвестицій в інфраструктурне забезпечення територій, оскільки це створює можливості для нарощування конкурентних переваг. Рішення з пулу можливостей інвестиційної складової маркетингу територій є обгрунтованими в даному контексті і сприяють досягненню стратегічних завдань, що стоять перед українськими регіонами в рамках просторового розвиткy.

Ефективність маркетингу території проявляється в підвищенні якості вироблених суспільних благ і соціально економічному розвитку території, маркетингу підприємства - в створенні найвищої цінності.

Природа комерційного маркетингу штучна, створюється разом з продуктом. При випуску продукції підприємству необхідно переконувати споживачів в його конкурентні переваги. Природу маркетингу території визначає іiї історія, політична і культурна системи. Він асоційований з історією і культурою, спирається на почуття приналежності і самосвідомість, тому територіальні слогани народжуються на території іiї жителями.

Маркетинг на рівні компанії носить централізований характер і фрінансується за рахунок її коштів. При цьому рішення найчастіше носять авторитарний або демократичний характер. У свою чергу маркетинг території може бути реалізований тільки на принципі соціального партнерства і спільного фрінансування з включенням максимально широкого кола учасників. Тому для території характерна низька централізація і висока неузгодженість дій.

У традиційному маркетингу підприємство розробляє продукт, визначає потенційних споживачів, потім розробляє план ефективного збуту товарів (послуг) на ринку. У маркетингу території в першу чергу проводиться аналіз і оцінка потенціалу території, вибирається цільова аудиторія, потім розробляється продукт і стратегія його просування. Така відмінність пов'язана з неможливістю трансформації фрізичних характеристик території для кращого сприйняття споживачем і підвищення конкурентоспроможності.

Аналізуючи подібності і відмінності традиційного та територіального маркетингу можна зробити такий висновок: незважаючи на подібні основи і принципи ведення діяльності, ключовими факторами успіху комерційних компаній $є$ швидкість, цілеспрямованість, мобільність і багатоканальність просування; для територій стратегія, комплексність, широке коло стейкхолдерів. Однак трансорормація методів та інструментів традиційного маркетингу в маркетингу території може сприя- ти підвищенню ефективності управління територією і забезпечити сталий соціально-економічний розвиток.

\section{ВИСНОВКИ}

Отже, маркетинг територій доцільно трактувати як управлінську діяльність зі стратегічного розвитку територій на основі фрормування і посилення її конкурентних переваг, які є значущими для влади, бізнесу, населення (як місцевого, так і тимчасово відвідує місце) і партнерів території. В цьому випадку під партнерами території розуміються будь-які зацікавлені в її розвитку суб'єкти, пов'язані з нею єдністю реалізованих проєктів.

Використання теорії маркетингу в територіальному управлінні сприятиме створенню органами влади і окремими особами максимального соціального ефекту за допомогою задоволення потреб населення (осіб, сім'ї, домашніх господарств) у суспільних благах, послугах, ідеях і створить передумови підвищення привабливості конкретної території як місця проживання та ведення діяльності. Маркетинговий підхід у територіальному управлінні дозволяє визначити і далі дати оцінку факторів конкурентоспроможності, уточнити місію та цілі управління територією.

Література:

1. Акимова О.Е., Богомолова И.В. Маркетинг территорий: аспекты реализации. Шахты, 2009. 115 с.

2. Дробязко І.М. Територіальний маркетинг як механізм підвищення ефективності діяльності органів місцевого самоврядування. Теорія та практика державного управління: зб. наук. пр. Х.: Вид-во ХарРІ НАДУ "Магістр", 2008. Вип. 2 (21). С. 149-153.

3. Котлер Ф., Асплунд К., Рейн И. Маркетинг мест. Привлечение инвестиций, предприятий, жителей и туристов в города, коммуны, регионы и страны Европы. СПб.: Стокгольмская школа экономики в Санкт-Петербурге, 2005. $382 \mathrm{c}$.

4. Лавров А.М., Сурнин В.С. Региональный маркетинг и тенденции его развития. Кемерово, 1994. 144 с.

5. Сачук Т.В. Териториальний маркетинг. СПб.: Питер, 2009. 368 c.

\section{References:}

1. Akymova, O.E. and Bohomolova, Y.V. (2009), Marketynh terrytoryj: aspekty realyzatsyy [Territory marketing: implementation aspects], Shakhty, Ukraine.

2. Drobiazko, I. M. (2008), "Territorial marketing as a mechanism for improving the efficiency of local governments", Teoriia ta praktyka derzhavnoho upravlinnia, vol. 2 (21), pp. 149-153.

3. Kotler, F. Asplund, K. and Rejn, Y. (2005), Marketynh mest. Pryvlechenye ynvestytsyj, predpryiatyj, zhytelej y turystov $v$ horoda, kommuny, rehyony y strany Evropy [Place marketing. Attracting investments, enterprises, residents and tourists to cities, communes, regions and countries of Europe], Stokhol'mskaia shkola ekonomyky v Sankt-Peterburhe, Sankt-Peterburh, Rosiia.

4. Lavrov, A.M. and Surnyn, V.S. (1994), Rehyonal'nyj marketynh y tendentsyy eho razvytyia [Regional marketing and tendencies of its development], Kemerovo, Rosiia.

5. Sachuk, T.V. (2009), Terytoryal'nyj marketynh [Territorial marketing], Pyter, Sankt-Peterburh, Rosiia. Cтаття надійшла до редакчї 18.10.2021 p. 